\title{
Analisis Kinerja Ekspor Subsektor Perkebunan Indonesia dan Pandemi Covid-19
}

\author{
Analysis of Indonesia's Plantation Subsector Export Performance and the Covid-19 \\ Pandemic
}

Wildan Nur Arrasyiid Sane Pratinda ${ }^{1}$, Rahmi Harta ${ }^{2}$

1,2 Departemen Ilmu Ekonomi, Fakultas Ekonomi dan Manajemen, Institut Pertanian Bogor

Jalan Agatis, Kampus IPB Dramaga, Bogor 16680, Indonesia

${ }^{1}$ Korespondensi: wildanarrasyiid1@gmail.com

[diterima: September 2021- revisi: November 2021-diterbitkan daring: Desember 2021]

\begin{abstract}
ABSTRAK
Pandemi Covid-19 telah berpengaruh besar pada aspek kehidupan, terutama perekonomian. Mayoritas sektorsektor perekonomian mengalami kontraksi selama masa pandemi. Namun selama masa pandemi, subsektor perkebunan mampu bertahan dengan kinerja yang positif. Hal tersebut dapat terlihat dari kontribusinya terhadap PDB, khususnya ekspor subsektor perkebunan yang mengalami pertumbuhan sebesar $10.68 \%$ jika dibandingkan dengan tahun 2019. Tujuan penelitian ini adalah untuk menganalisis faktor-faktor yang memengaruhi ekspor subsektor perkebunan Indonesia selama periode 1990-2020 dengan menggunakan metode regresi berganda. Selanjutnya, penelitian ini menganalisis kinerja ekspor subsektor perkebunan selama masa pandemi Covid-19 dan dampaknya terhadap output, pendapatan, dan tenaga kerja dengan menggunakan analisis Input-Output. Hasil penelitian bahwa menunjukkan faktor-faktor yang memengaruhi ekspor subsektor perkebunan Indonesia adalah PDB nominal Indonesia, harga ekspor komoditas subsektor perkebunan, produktivitas subsektor perkebunan, dan kurs rupiah terhadap dolar AS. Sementara ekspor subsektor perkebunan terutama selama masa pandemi Covid-19. Hasil analisis mengindikasikan bahwa peningkatan kinerja subsektor perkebunan perlu dilakukan untuk mendorong peningkatan produktivitas sehingga dapat mempengaruhi peningkatan kinerja ekspor subsektor perkebunan.
\end{abstract}

Kata kunci: Ekspor, Perkebunan, Input-Output, Covid-19

\begin{abstract}
The Covid-19 pandemic has had a major impact on aspects of life, especially the economy. The majority of economic sectors contracted during the pandemic. However, during the pandemic, the plantation sub-sector was able to survive with positive performance. This can be seen from its contribution to GDP, especially exports of the plantation sub-sector which grew by 10.68 percent when compared to 2019. The purpose of this study is to analyze the factors that affect Indonesia's plantation sub-sector exports during the period 1990-2020 using the multiple regression method. . Furthermore, this study analyzes the export performance of the plantation subsector during the Covid-19 pandemic and its impact on output, income, and labor using Input-Output analysis. The results of the study indicate that the factors that affect Indonesia's plantation sub-sector exports are Indonesia's nominal GDP, export prices of plantation sub-sector commodities, plantation sub-sector productivity, and the rupiah exchange rate against the US dollar. Meanwhile, exports of the plantation subsector, especially during the Covid-19 pandemic. The results of the analysis indicate that improving the performance of the plantation sub-sector needs to be carried out to encourage increased productivity so that it can affect the increase in export performance of the plantation sub-sector.
\end{abstract}

Keywords: Export, Plantation, Input-Output, Covid-19

JEL classification: D57, F16, I18, Q13 


\section{PENDAHULUAN}

Mewabahnya Corona Virus Desease 2019 (Covid-19) membuat pemerintah menerapkan kebijakan karantina wilayah atau pembatasan aktivitas masyarakat demi mengurangi penyebaran virus. Jika di tinjau dari sisi permintaan, kebijakan tersebut menyebabkan terjadinya penurunan aktivitas manusia dan transportasi sehingga mengganggu aktivitas perdagangan dan meningkatkan biaya transportasi (Purba 2020). Sementara dari sisi penawaran, Covid-19 menyebabkan penurunan produktivitas, investasi, dan pendanaan sehingga mengganggu rantai pasok global. Hal tersebut telah memberikan dampak pada perlambatan ekonomi global, termasuk Indonesia.

Menurut Badan Pusat Statistik (BPS), perekonomian nasional mengalami penurunan jika di lihat dari sisi pengeluaran pada triwulan II $2020(y-o-y)$ dibandingkan tahun 2019. Konsumsi rumah tangga mengalami penurunan sebesar $5.51 \%$ sedangkan komponen ekspor mengalami penurunan sebesar $11.66 \%$. Penurunan ekspor disebabkan karena permintaan global yang terkontraksi akibat pandemi Covid-19 (ILO 2020). Selain itu, penurunan kinerja ekspor Indonesia disebabkan karena sebagian besar mitra dagang utama Indonesia mengalami pertumbuhan ekonomi yang negatif (Purba et al.
2020).

Pandemi telah berdampak besar pada banyak aspek kehidupan, terutama ekonomi baik secara makro maupun sektoral. Selama masa pandemi Covid-19 atau tahun 2020, Produk Domestik Bruto (PDB) Indonesia mengalami penurunan yang cukup tinggi yaitu $-2.07 \%$. Hal tersebut disebabkan karena kontraksi perekonomian yang terjadi hampir diseluruh lapangan usaha. Namun, sektor pertanian, kehutanan, dan perikanan mampu tumbuh positif sebesar 2.11\% (BPS 2021). Pertumbuhan positif tersebut didukung oleh pertumbuhan produksi subsektor perkebunan terutama kelapa sawit, cengkeh, dan teh (Sambuaga 2020).

Berdasarkan Gambar 1 yang menunjukkan kontribusi sektor pertanian, kehutanan, dan perikanan terhadap PDB Indonesia dari tahun 2016-2020, subsektor perkebunan secara konsisten memberikan kontribusi terbesar diantara subsektor pertanian, kehutanan, dan perikanan lainnya. Selama masa pandemi Covid19 atau pada tahun 2020, kontribusi subsektor perkebunan terhadap PDB Indonesia justru mengalami peningkatan daripada tahun 2019 atau sebelum terjadinya pandemi. Artinya, subsektor perkebunan mampu menjadi buffer dan memiliki daya tahan (resilience) terhadap goncangan atau krisis (Azahari et al. 2020).

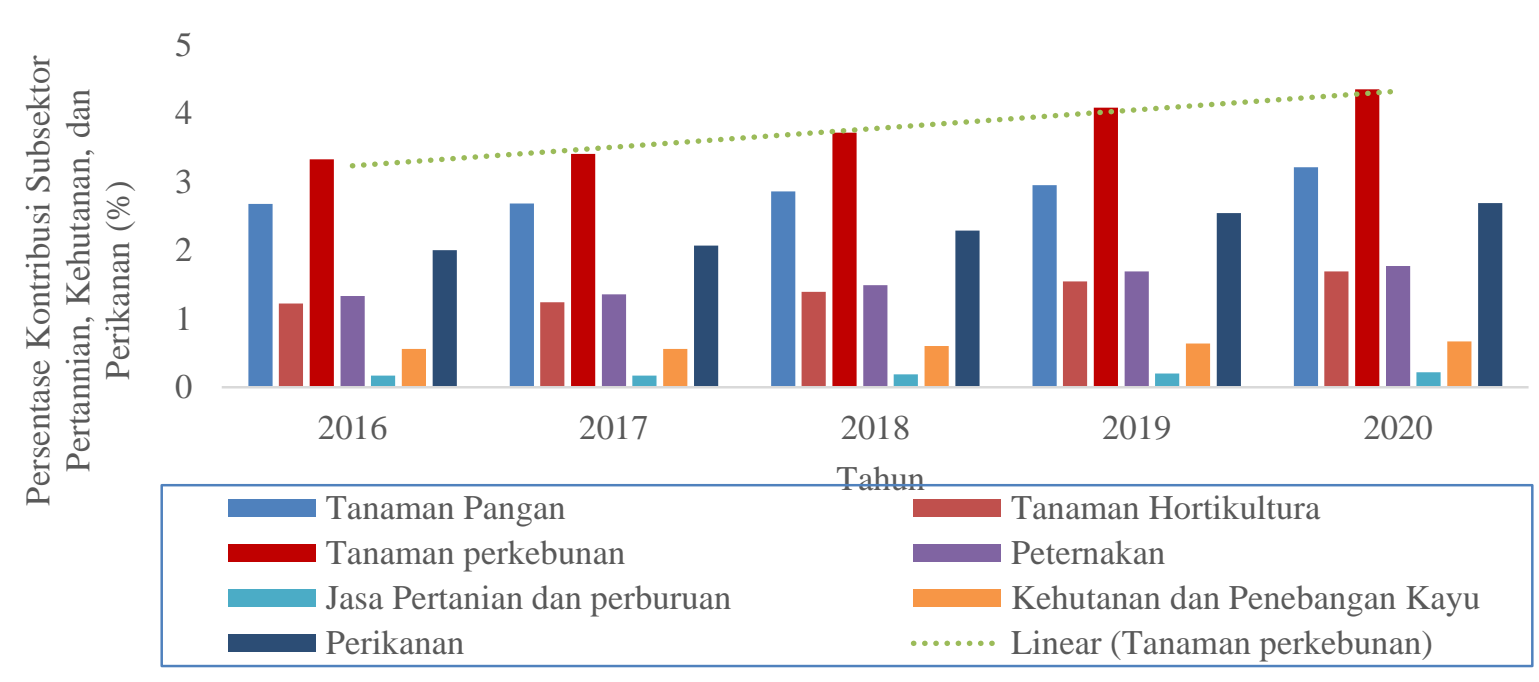

Sumber: BPS (2020), diolah

Gambar 1. Kontribusi subsektor pertanian, kehutanan, dan perikanan terhadap PDB Indonesia tahun 2016-2020 (persentase). 
Sebagaimana krisis moneter yang melanda Indonesia pada tahun 2008, subsektor perkebunan tetap mampu memberikan kontribusi yang positif terhadap perekonomian melalui sumbangannya terhadap devisa negara (Azahari et al. 2020). Selain itu, adanya target peningkatan ekspor melalui program Gerakan Tiga Kali Ekspor (Gratieks) dimana salah satu fokusnya adalah pada komoditas perkebunan andalan membuat subsektor perkebunan memiliki posisi yang semakin kuat dalam menghadapi krisis, terutama pandemi Covid-19 yang sedang melanda. (Ditjenbun 2020).

Selain kontribusinya terhadap PDB, subsektor perkebunan juga mampu menjadi penyumbang terbesar ekspor di sektor pertanian dengan kontribusi sebesar 90.92\% (BPS 2020). Secara lebih rinci, total nilai ekspor subsektor perkebunan dari tahun 2016-2020 dapat di lihat pada Gambar 2. Total nilai ekspor subsektor perkebunan cenderung berfluktuatif. Selama masa pandemi Covid-19 atau pada tahun 2020, total nilai ekspor subsektor perkebunan adalah sebesar 22.39 Miliar USD atau mengalami pertumbuhan sebesar $10.68 \%$ jika dibandingkan dengan tahun 2019 dimana pandemi belum terjadi. Peningkatan nilai ekspor tersebut terjadi karena adanya peningkatan harga komoditas perkebunan yang diekspor sebagai akibat dari melemahnya dolar Amerika Serikat (Nainggolan et al. 2021). Selain itu, peningkatan nilai ekspor subsektor perkebunan disebabkan karena adanya lonjakan permintaan komoditas perkebunan terutama pada komoditas kelapa sawit dan kelapa (Ditjenbun 2020). Hal ini menunjukkan bahwa peluang ekspor komoditas perkebunan sebagai salah satu penyumbang devisa negara masih terus mengalami peningkatan walaupun di tengah krisis yang sedang melanda Indonesia dan dunia.

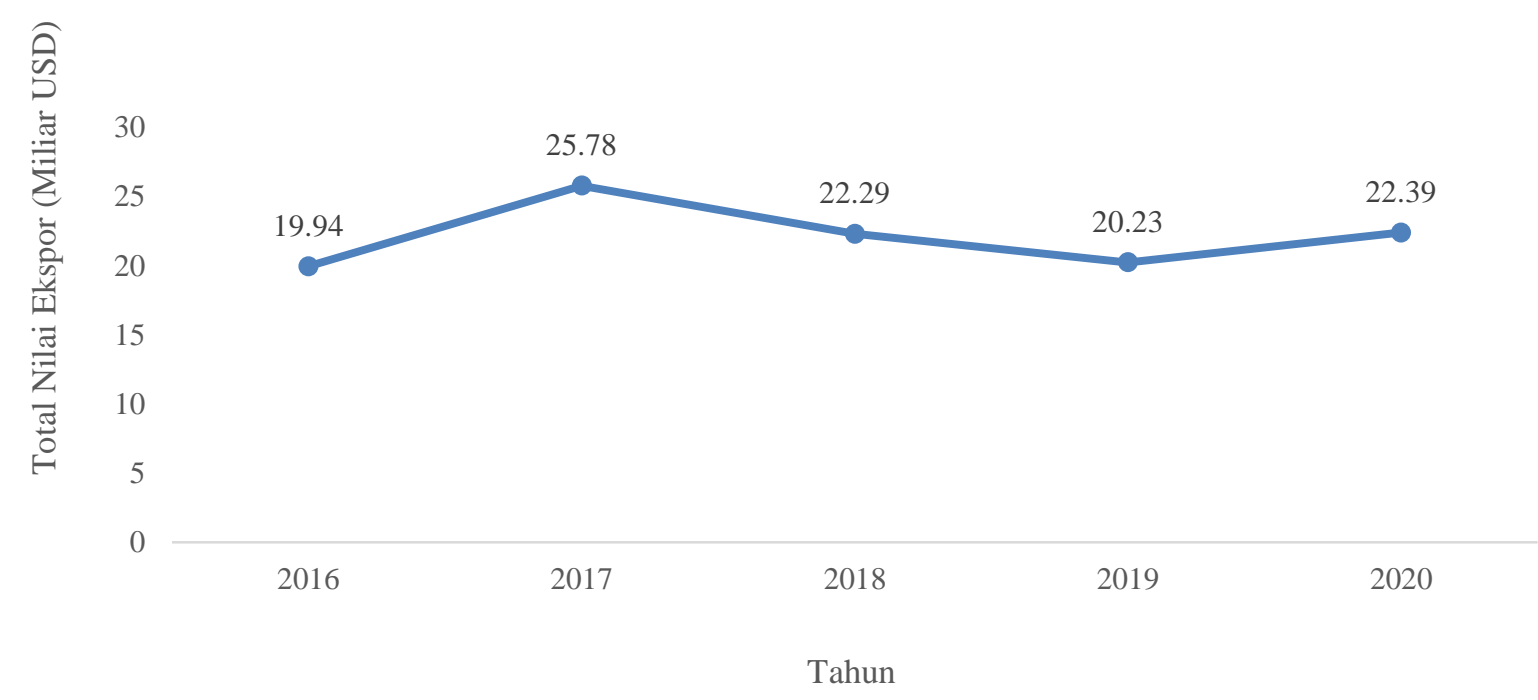

Sumber: BPS (2020), diolah

Gambar 2. Total nilai ekspor komoditas perkebunan Indonesia tahun 2016-2020 (Miliar USD)

Berdasarkan paparan di atas dapat bagaimana dampak pandemi Covid-19 terhadap diketahui bahwa, subsektor perkebunan Indonesia kinerja ekspor subsektor perkebunan dalam memiliki kontribusi yang besar terhadap meningkatkan output, pendapatan, dan perekonomian melalui sumbangan kepada devisa penyerapan tenaga kerja sektor-sektor dan PDB Indonesia. Adanya gangguan pada perekonomian Indonesia. Selain itu, karena ekspor komoditas perkebunan tentu akan subsektor perkebunan memiliki sejarah panjang berpengaruh terhadap perekonomian nasional. dalam perekonomian Indonesia, maka penelitian Maka dari itu, pendalaman mengenai dampak ini berusaha untuk mengetahui faktor-faktor apa pandemi Covid-19 terhadap kinerja ekspor saja yang memengaruhi kinerja ekspor subsektor subsektor perkebunan menjadi sangat menarik perkebunan Indonesia selama 31 tahun terakhir. untuk dikaji. Terutama untuk menjawab 


\section{TINJAUAN PUSTAKA}

\section{Perdagangan Internasional}

Perdagangan internasional merupakan perjanjian antara penduduk suatu negara dengan penduduk negara lain untuk melakukan transaksi bisnis berdasarkan persetujuan bersama. Penduduk bisa berupa antar individu, individu dengan pemerintah, dan pemerintah dalam suatu negara dengan negara lain (Oktaviani dan Novianti 2009). Perdagangan mencerminkan kegiatan ekspor dan impor suatu negara dan merupakan salah satu komponen pembentuk PDB dari suatu negara.

Gambar 3 menjelaskan adanya perdagangan internasional antara negara $X$ dan negara $\mathrm{Y}$. $\mathrm{D}_{\mathrm{X}}$ dan $\mathrm{S}_{\mathrm{X}}$ adalah kurva permintaan dan penawaran negara $X$, sedangkan $D_{Y}$ dan $S_{Y}$ merupakan kurva permintaan dan penawaran untuk negara $Y$. Negara $X$ sebagai negara pengekspor dan negara $\mathrm{Y}$ sebagai negara pengimpor. Terjadinya perdagangan internasional disebabkan oleh kelebihan pasokan atau penawaran dari negara $\mathrm{X}$ dan kelebihan permintaan dari negara $\mathrm{Y}$, dimana harga komoditas $\mathrm{M}$ di negara $\mathrm{X}$ sebesar $\mathrm{P} 1$ yang menyebabkan terjadinya kelebihan penawaran pada komoditinya. Sementara pada negara $Y$ harga komoditas $\mathrm{M}$ sebesar P3 yang menyebabkan terjadinya kelebihan permintaan pada komoditinya.

Berdasarkan harga relatif P1 dan P3, pada saat perdagangan internasional antara negara $X$ dan Y, diasumsikan bahwa tingkat harga internasional pada titik P2 tidak terdapat biaya pengiriman dalam proses perdagangan internasional ini, sehingga negara $\mathrm{X}$ dengan tingkat harga domestik di P1 akan mengekspor hasil kelebihan produksinya. Sementara tingkat harga domestik di negara $\mathrm{Y}$ adalah $\mathrm{P}$ 3, negara $\mathrm{Y}$ akan mengimpor atas kekurangan produksinya. Hubungan penawaran dan permintaan kedua negara ini lah yang menyebabkan terjadinya keseimbangan internasional di titik $\mathrm{E}^{*}$ atau pada tingkat harga P2 (Salvatore 1997).

\section{Panel A \\ Pasar di Negara X Untuk komoditi M}

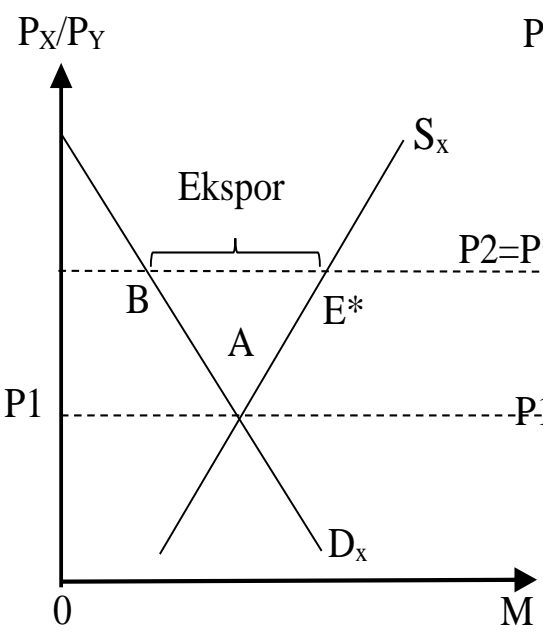

Panel B

Hubungan Perdagangan

Internasional dalam

Komoditi M
Panel C

Pasar di Negara Y untuk Komoditi M

Sumber: Salvatore (1997)

Gambar 3. Kurva perdagangan internasional 


\section{Kerangka Tabel Input-Output}

Tabel Input-Output pertama kali diperkenalkan pada tahun 1930-an oleh W. Leontief. Tabel Input-Output (I-O) ialah matriks yang berisi informasi tentang pertukaran barang dan jasa serta tentang hubungan antar sektor ekonomi di suatu wilayah selama periode waktu tertentu (BPS 2021). Matriks Tabel Input-Output sepanjang baris menjelaskan penggunaan output dari suatu sektor yang digunakan untuk memenuhi permintaan antara dan akhir, sedangkan matriks di sepanjang kolom menjelaskan penggunaan input oleh suatu sektor dalam proses produksinya baik itu input antara maupun input primer (Sahara 2017).

Tabel I-O telah digunakan secara luas dalam berbagai penelitian seperti yang dilakukan oleh Lomban (2021), Wibowo (2013), dan Nussy (2021). Secara umum penelitian tersebut meneliti bagaimana dampak dari adanya aktivitas ekonomi berupa ekspor atau perubahan permintaan akhir sektor-sektor perekonomian. Sejalan dengan Malba dan Taher (2016) bahwa salah satu kegunaan Tabel I-O adalah untuk analisis dampak perubahan permintaan akhir terhadap sektor-sektor ekonomi suatu wilayah.

Format Tabel I-O terdiri dari kerangka matriks berukuran " $n \times n$ ". Matriks pada Tabel IO dibedakan menurut sifat dan jenis transaksinya serta terdapat beberapa kuadran dalam Tabel I-O yang masing-masing kuadrannya memiliki suatu hubungan tertentu. Untuk menampilkan dan mendeskripsikan gambar Tabel I-O dapat di lihat pada Tabel 1.

Tabel 1. Kerangaka tabel Input-Output

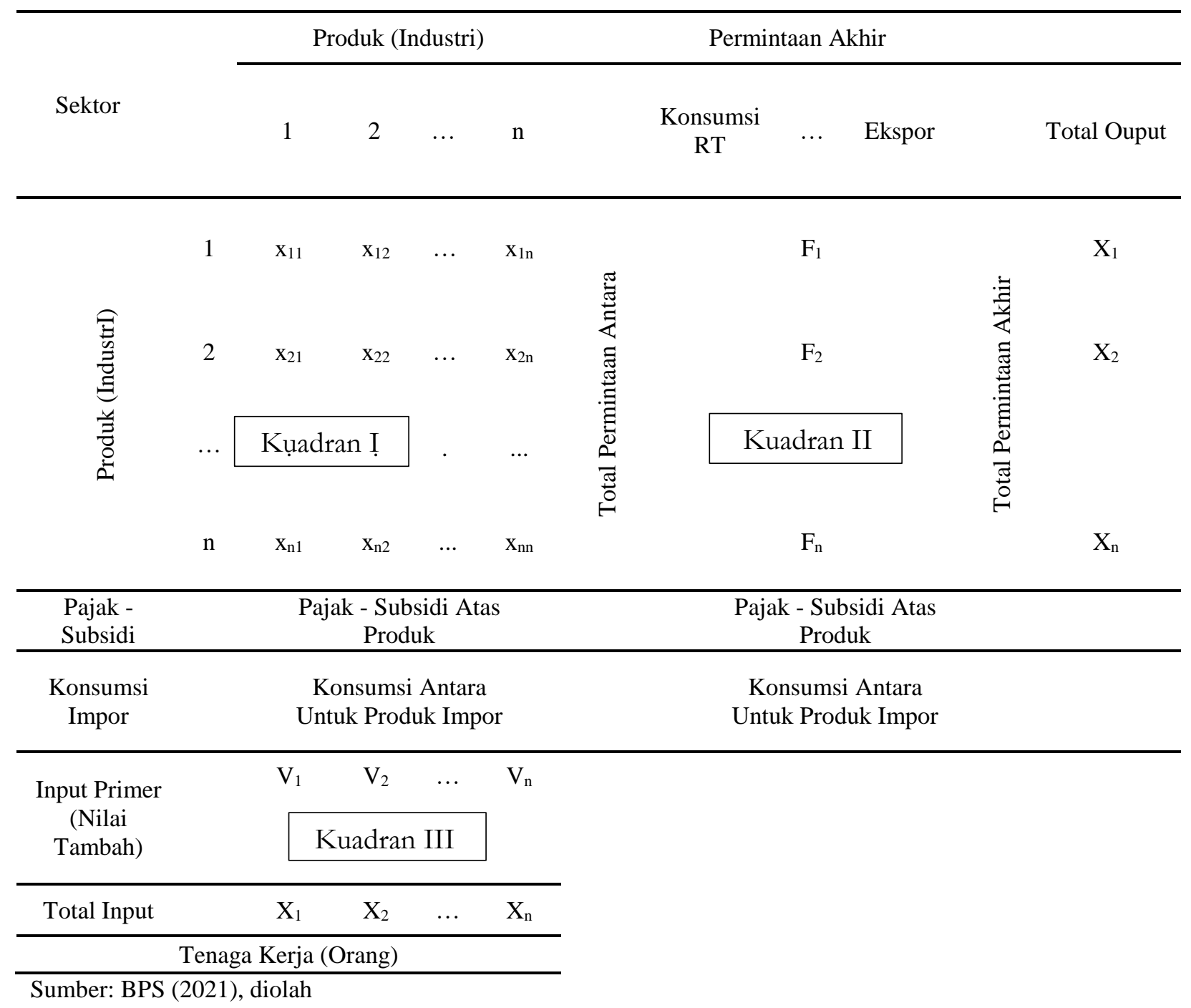


Berdasarkan Tabel persamaan pada Tabel I-O, bila ditampilkan secara baris dapat dituliskan dengan persamaan aljabar sebagai berikut:
$(\mathrm{I}-\mathrm{A})=$ matriks Leontief
$(\mathrm{I}-\mathrm{A})^{-1}=$ matriks kebalikan Leontief terbuka

Berdasarkan persamaan (4) dapat diketahui $\begin{array}{cccccccccccccc}\mathrm{x}_{11} & + & \mathrm{x}_{12} & + & \ldots & + & \mathrm{x}_{\mathrm{n} 1} & + & \mathrm{V}_{1} & = & \mathrm{X}_{1} & \text { bahwa permintaan akhir memiliki hubungan } \\ \mathrm{x}_{12} & + & \mathrm{x}_{22} & + & \ldots & + & \mathrm{x}_{\mathrm{n} 2} & + & \mathrm{V}_{2} & = & \mathrm{X}_{2} & \text { dengan } & \text { output setiap sektor dengan matriks } \\ \vdots & \vdots & \vdots & \vdots & \vdots & \vdots & \vdots & \vdots & \vdots & \vdots & \vdots & \text { kebalikan leontief sebagai koefisien antaranya. }\end{array}$ $\mathrm{x}_{1 \mathrm{n}}+\mathrm{x}_{2 \mathrm{n}}+\ldots+\mathrm{x}_{\mathrm{nn}}+\mathrm{V}_{\mathrm{n}}=\mathrm{X}_{\mathrm{n}}$ Matriks kebalikan ini dapat digunakan sebagai

(1)

Secara umum persamaan di atas dapat dirumuskan sebagai berikut:

$\sum_{j=1}^{n} x_{i j}+F_{i}=X_{i} ;$ untuk n

$$
=1,2,3 \text {, dan seterusnya }
$$

$\mathrm{x}_{\mathrm{ij}}$ merupakan banyaknya output dari sektor i yang digunakan sebagai input oleh sektor $\mathrm{j}$, sedangkan $\mathrm{F}_{\mathrm{i}}$ mewakili permintaan akhir dari sektor i serta $\mathrm{X}_{\mathrm{i}}$ merupakan jumlah output sektor i. Berdasarkan persamaan 1 di atas, matriks koefisien teknis (koefisien teknologi) adalah sebagai berikut:

$a_{i j}=\frac{x_{i j}}{X_{j}}$

Jika persamaan (2) disubstitusikan ke persamaan (1) maka akan didapatkan persamaan sebagai berikut:

$\begin{array}{ccccccccc}a_{11} \mathrm{X}_{1} & + & a_{12} \mathrm{X}_{2} & + & \ldots & + & a_{1 n} \mathrm{X}_{\mathrm{n}} & + & \mathrm{F}_{1} \\ a_{21} \mathrm{X}_{1} & + & a_{22} \mathrm{X}_{2} & + & \ldots & + & a_{2 n} \mathrm{X}_{\mathrm{n}} & + & \mathrm{F}_{2} \\ \vdots & \vdots & \vdots & \vdots & \vdots & \vdots & \vdots & \vdots & \vdots \\ a_{n 1} \mathrm{X}_{1} & + & a_{n 2} \mathrm{X}_{2} & + & \ldots & + & a_{n n} \mathrm{X}_{\mathrm{n}} & + & \mathrm{F}_{\mathrm{n}}\end{array}$ (3)

Jika ditulis dalam bentuk matriks, maka persaamaan (3) adalah sebagai berikut:

$$
\begin{aligned}
& \left|\begin{array}{cccc}
\mathrm{a}_{11} & \mathrm{a}_{12} & \ldots & \mathrm{a}_{1 \mathrm{n}} \\
\mathrm{a}_{21} & \mathrm{a}_{22} & \ldots & \mathrm{a}_{2 \mathrm{n}} \\
\vdots & \vdots & \vdots & \vdots \\
\mathrm{a}_{\mathrm{n} 1} & \mathrm{a}_{\mathrm{n} 2} & \cdots & \mathrm{a}_{\mathrm{nn}}
\end{array}\right|\left|\begin{array}{c}
\mathrm{X}_{1} \\
\mathrm{X}_{2} \\
\vdots \\
\mathrm{X}_{\mathrm{n}}
\end{array}\right|+\left|\begin{array}{c}
\mathrm{F}_{1} \\
\mathrm{~F}_{2} \\
\vdots \\
\mathrm{F}_{\mathrm{n}}
\end{array}\right|=\left|\begin{array}{c}
\mathrm{X}_{1} \\
\mathrm{X}_{2} \\
\vdots \\
\mathrm{X}_{\mathrm{n}}
\end{array}\right| \\
& \mathrm{A} \quad \mathrm{X}+\mathrm{F}=\mathrm{X}(4)
\end{aligned}
$$

Jika ditulis dalam bentuk persamaan menjadi:

$\mathrm{AX}+\mathrm{F}=\mathrm{X}$ atau $(\mathrm{I}-\mathrm{A}) \mathrm{X}=\mathrm{F}$

$\mathrm{X}=(\mathrm{I}-\mathrm{A})^{-1} \mathrm{~F}$

Keterangan:

$$
\begin{array}{ll}
\mathrm{I} & =\text { matriks idenstitas } \\
\mathrm{F} & =\text { permintaan akhir } \\
\mathrm{X} & =\text { jumlah output }
\end{array}
$$
alat analisis ekonomi karena menunjukkan adanya hubungan atau saling keterkaitan.

\section{Analisis Regresi Berganda}

Regresi linear berganda ialah pengamatan yang didasarkan atas dua atau lebih variabel dengan tujuan untuk mengetahui hubungan dan menunjukkan arah hubungannya. Menurut Priyatno (2012) regresi linear berganda digunakan untuk memprediksi nilai variabel dependen atas dasar variabel independen. Persamaan analisis regresi linear berganda dalam penelitian ini adalah sebagai berikut:

Ln Nilai Ekspor ${ }_{t}=\alpha+\beta_{1}$ Ln Produk Domestik Bruto $_{\mathrm{t}}+\beta_{2}$ Ln Harga Ekspor ${ }_{\mathrm{t}}$ $+\beta_{3}$ Ln Produktivitas $t+\beta_{4}$ Kurs Rupiah terhadap Amerika Serikat ${ }_{t}+$ Error Term $_{i t}$

\section{Produk Domestik Bruto}

$=\mathrm{X}_{\mathfrak{P}}$
$=\mathrm{X}_{2}$ roduk Domestik Bruto (PDB) adalah
salah $\underset{\vdots}{\vdots}$ satu indikator yang digunakan untuk
mengetahui keadaan perekonomian suatu negara dalam kurun waktu tertentu (BPS 2021). Ada dua jenis PDB yaitu, PDB atas dasar harga berlaku nominal yang menunjukkan kapasitas sumber daya ekonomi yang dihasilkan oleh suatu negara dan PDB atas dasar harga konstan menunjukkan pertumbuhan ekonomi makro. PDB dapat menggambarkan pertumbuhan ekonomi dan tingkat pendapatan nasional karena mengandung komponen konsumsi (C), investasi (I), pengeluaran pemerintah (G), dan ekspor neto (NX) (Hasan dan Azis 2018).

Peningkatan PDB dapat meningkatkan daya beli masyarakat untuk impor. Sisi lain, peningkatan PDB menyebabkan masyarakat mengekspor ke negara lain karena kemampuan masyarakat untuk memproses proses produksi 
meningkat (Dewi 2018). Menurut Mankiw (2006) PDB dan ekspor memiliki hubungan yang positif, artinya jika perekonomian suatu negara meningkat, maka kapasitas produksi negara tersebut akan meningkat dan berdampak pada peningkatan penawaran barang sehingga ekspor dari negara tersebut akan mengalami peningkatan.

\section{Harga Ekspor}

Harga ekspor atau harga internasional adalah salah satu faktor yang dapat memengaruhi ekspor komoditas. Rumus umum harga ekspor adalah perbandingan antara nilai ekspor dengan volume ekspor suatu produk atau komoditas ekspor. Kristanto (2011) menyatakan harga memiliki tiga fungsi utama, yaitu menentukan volume penjualan, menentukan keuntungan, dan menentukan citra atau image produk. Menurut hukum permintaan, apabila harga barang naik, jumlah barang yang dibeli berkurang, dan sebaliknya apabila harga barang turun, jumlah yang dibeli bertambah (Goenadhi dan Nobaiti 2017).

Mankiw (2006) menjelaskan bahwa ketika supply ekspor meningkat maka akan berpengaruh terhadap harga ekspor, artinya apabila harga naik, permintaan dan ekspor turun, dan sebaliknya, apabila harga turun, permintaan dan ekspor naik. Soekartawi (2005) menjelaskan bahwa harga internasional merupakan salah faktor yang dapat memengaruhi ekspor suatu produk atau komoditas, serta hubungan anatar harga internasional dengan volume ekspor ialah ketika harga ekspor produk di pasar internasional lebih tinggi daripada di pasar domestik, maka jumlah komoditas yang di ekspor meningkat. Oleh karena itu, hubungan harga ekspor dapat berpengaruh positif dan negatif terhadap nilai ekspor.

\section{Produktivitas}

Produktivitas merupakan perbandingan antara hasil yang diterima dengan luas lahan atau biaya yang digunakan (Siringo dan Daulay 2014). Menurut BPS (2021) komponen yang terdapat pada rumusan produktivitas suatu komoditas adalah perbandingan antara jumlah produksi dan luas panen suatu komoditas. Sehingga dapat dikatakan bahwa komponen yang memengaruhi produktivitas adalah jumlah produksi dan luas panen suatu komoditas. Secara teoritis, peningkatan produktivitas suatu sektor menyebabkan peningkatan produksi di sektor yang bersangkutan dan sektor terkait lainnya, yang dapat diartikan sebagai perubahan kurva penawaran ke kanan akibat peningkatan produktivitas (Gultom 2012). Sehingga dengan meningkatnya produktivitas akan berdampak terhadap peningkatan permintaan dari komoditas tersebut. Selanjutnya Mankiw (2006) menjelaskan bahwa ketika terjadi peningkatan kapasitas produksi dalam hal ini adalah produktivitas, maka kelebihan produksi akan berdampak pada peningkatan ekspor.

\section{Kurs Rupiah terhadap Dolar Amerika Serikat}

Kurs atau nilai tukar ialah hubungan antara harga suatu mata uang terhadap nilai mata uang negara lain. Salah satu faktor yang memengaruhi ekspor suatu komoditas adalah nilai tukar suatu negara terhadap negara lain. Jika nilai tukar rupiah terhadap dolar Amerika Serikat (AS) naik secara nominal, sebagai contoh dari Rp 12 000/\$ menjadi Rp 13 000/\$ mengartikan rupiah mengalami depresiasi karena besarnya rupiah yang harus dikeluarkan untuk membeli 1 dolar menjadi lebih banyak, dengan kata lain rupiah mengalami pelemahan (Maulana 2020). Apabila nilai tukar domestik negara importir mengalami depresiasi terhadap mata uang negara eksportir, maka kondisi ini menunjukkan bahwa harga suatu produk di negara importir lebih murah dan produk di negara eksportir relatif lebih mahal. Sehingga akan mendorong negara importir untuk menurunkan nilai maupun volume impornya dan negara importir akan membutuhkan lebih banyak uang untuk membeli barang impor dari negara lain (Hotsawadi 2020).

\section{Pengaruh Covid-19 terhadap Ekspor}

Pandemi Covid-19 membawa pengaruh besar terhadap perdagangan internasional Indonesia dan ekonomi global. Akibat pandemi, terjadi perubahan besar dalam pola perdagangan dunia seperti adanya sistem lockdown yang 
diterapkan oleh beberapa negara sehingga mempengaruhi waktu atau biaya yang dibutuhkan dalam pengiriman barang, penerapan protokol kesehatan yang mengakibatkan bertambahnya biaya pengiriman dan terhambatnya distribusi barang ke tempat tujuan. Hal tersebut berakibat kepada permintaan barang itu sendiri atau secara luasnya akan berpengaruh kepada permintaan agregat (AD) suatu negara. Permintaan agregat (AD) terdiri dari komponen pendapatan nasional, yaitu konsumsi (C), Investasi (I), pengeluaran pemerintah (G), dan ekspor bersih (NX). Apabila terjadi penurunan terhadap permintaan barang tersebut, maka akan berpengaruh kepada ekspor yang menurun pada barang tersebut. Sehingga dapat terjadi penurunan terhadap pendapatan nasional suatu negara.

Berdasarkan Gambar 4, titik keseimbangan awal berada pada $\mathrm{E}_{0}$, adanya penurunan aktivitas komponen NX akan menyebabkan pergeseran pada kurva permintaan agregat $(\mathrm{AD})$ dari $\mathrm{AD}_{0}$ menjadi $\mathrm{AD}_{1}$. Hal tersebut menyebabkan titik keseimbangan bergeser dari $\mathrm{E}_{0}$ menjadi $\mathrm{E}_{1}$, yang berarti bahwa pendapatan nasional akan menurun dari $\mathrm{Y}_{0}$ menjadi $\mathrm{Y}_{1}$. Berdasarkan penjelasan tersebut akibat adanya penurunan aktivitas pada ekspor akan menyebabkan terjadinya penurunan pada pertumbuhan ekonomi suatu negara atau pendapatan suatu negara.

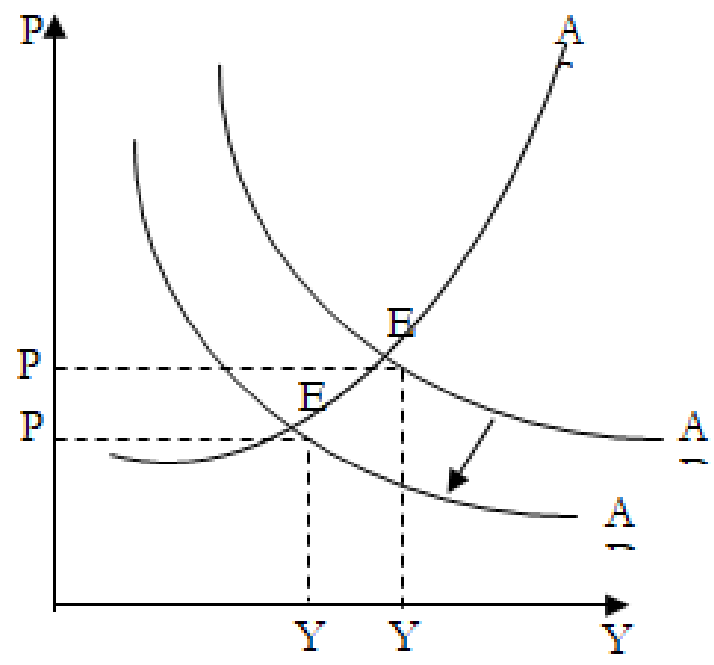

Gambar 4. Kurva Pergeseran AD-AS (Mankiw, 2006)

\section{Penelitian Terdahulu}

Berbagai literatur sebelumnya telah meneliti berbagai faktor yang berpengaruh terhadap ekspor, khususnya di Indonesia dengan menggunakan model parsial, khususnya model ekonometrik. (Raharja dan Setyari 2020; Berata dan Setiawina 2017; Segarani dan Dewi 2015). Raharja dan Setyari (2020) menjelaskan terkait determinan ekspor komputer Indonesia ke negara tujuan dari tahun 1989-2017. Hasil penelitiannya menunjukkan bahwa nilai tukar dolar, tingkat inflasi, dan produktivitas berpengaruh positif dan signifikan terhadap nilai ekspor komputer Indonesia. Berata dan Setiawina (2017) meneliti mengenai pengaruh luas lahan, jumlah produksi, kurs dolar Amerika Serikat, dan Inflasi terhadap ekspor kakao Indonesia selama tahun 1994-2013 dengan metode analisis regresi berganda. Hasil penelitian mengungkapkan bahwa luas lahan, jumlah produksi, kurs dolar AS, dan inflasi secara simultan berpengaruh signifikan terhadap ekspor kakao Indonesia. Begitu pula Segarani dan Dewi (2015) yang meneliti terkait pengaruh luas lahan, jumlah produksi, dan kurs dolar pada ekspor cengkeh di Indonesia dari tahun 19932012 dengan menggunakan model regresi liner berganda. Hasil penelitian menunjukkan bahwa luas lahan, jumlah produksi, dan nilai tukar dolar 
AS memiliki pengaruh positif dan signifikan terhadap volume ekspor cengkeh di Indonesia. Beberapa kajian yang telah disebutkan tersebut, jelas terlihat bahwa model ekonometrika merupakan analisis parsial yang berfokus pada hubungan kausal antara berbagai faktor yang mempengaruhi ekspor dan pertumbuhan ekonomi.

Selanjutnya, pengaruh pandemi Covid-19 terhadap perekonomian khususnya sektor pertanian termasuk perkebunan sudah di bahas oleh Purba et al. (2020), Azahari et al. (2020), serta Sudaryanto dan Sudaryono (2020). Namun, hanya sedikit kajian yang meneliti dampak perubahan nilai ekspor terhadap kinerja ekonomi dengan menggunakan model Input-Output (I-O). Dengan menggunakan model I-O, dampak perubahan nilai ekspor akibat adanya pandemi Covid-19 pada suatu sektor tertentu terhadap pertumbuhan ekonomi, penyerapan tenaga kerja, pendapatan rumah tangga serta neraca perdagangan (kinerja impor atau ekspor) dapat diketahui seperti pada penelitian Lomban (2021) dan Nussy (2021).

Sudaryanto dan Suharyono (2020) menjelaskan bahwa sektor pertanian telah menjadi penggerak perekonomian Indonesia selama masa pandemi Covid-19. Padahal, struktur perekonomian Indonesia sebelumnya didominasi oleh sektor industri dan jasa. Dominasi sektor pertanian selama pandemi didukung oleh subsektor perkebunan yang konsisten mengalami pertumbuhan selama masa pandemi berkat peningkatan produksi dan ekspor kelapa sawit, kelapa, dan tembakau. Pusdatin (2020) menjelaskan bahwa, pertumbuhan positif sektor pertanian termasuk itu subsektor perkebunan didukung oleh meningkatnya stimulus ekonomi seperti kredit usaha rakyat (KUR), subsidi transportasi, dan peningkatan stabilitas harga, sehingga turut memacu peningkatan produksi. Selain itu, menurut Azahari et al. (2020), subsektor perkebunan secara historikal telah bertahan dari beberapa krisis ekonomi seperti pada tahun 1998 dan 2008. Menurut Purba et al. (2020), subsektor perkebunan mampu memberikan kontribusi positif baik itu terhadap pertumbuhan ekonomi maupun terhadap PDB Indonesia. Dengan kata lain, pandemi Covid-19 tidak memberikan pengaruh yang signifikan terhadap kinerja subsektor perkebunan.

Secara khusus, Lomban (2021) telah mendalami kinerja ekspor sektor pertanian Indonesia dengan menggunakan model I-O selama masa pandemi Covid-19. Hasil penelitian menunjukkan bahwa dampak perubahan nilai ekspor sektor pertanian pada masa pandemi Covid-19 tahun 2020 yang berkontribusi penting bagi peningkatan output, pendapatan, dan tenaga kerja adalah kelapa sawit, kelapa, serta unggas dan hasil-hasilnya. Sementara sektor yang mendapatkan dampak penurunan tertinggi adalah kopi dan rumput laut dan sejenisnya. Selain itu, Nussy (2021) telah melakukan penelitian terhadap kinerja ekspor sektor agroindustri selama masa pandemi Covid-19 dengan model IO. Hasil penelitian menunjukkan bahwa perubahan nilai ekspor sektor agroindustri selama masa pandemi Covid-19 telah memberikan dampak positif pada padi, kelapa sawit, dan peternakan

Sebagian besar studi sebelumnya berfokus pada sektor pertanian secara luas dan kurang memperhatikan kontribusi subsektornya termasuk subsektor perkebunan. Padahal seperti yang dijelaskan pada kajian-kajian sebelumnya, subsektor perkebunan memiliki daya tahan yang kuat terhadap guncangan atau krisis sehingga mampu berdampak pada perekonomian. Maka dari itu, penelitian ini secara khusus memberikan kontribusi literatur dengan mengkaji dampak perubahan nilai ekspor di subsektor perkebunan terhadap pertumbuhan ekonomi, penyerapan tenaga kerja, dan pendapatan rumah tangga selama masa pandemi Covid-19. Selanjutnya dalam penelitian ini juga dikaji faktor-faktor apa saja yang mempengaruhi kinerja ekspor subsektor perkebunan selama 30 tahun terakhir untuk memperkuat analisis.

\section{METODE}

\section{Jenis dan Sumber Data}

Penelitian mengenai kinerja ekspor subsektor perkebunan ini menggunakan data sekunder yang bersifat kuantitatif. Data yang 
digunakan ialah data time series selama 31 tahun, yaitu dari tahun 1990-2020. Nilai ekspor perkebunan Indonesia digunakan sebagai variabel dependen (minyak kelapa sawit, kopi, teh, cengkeh, tembakau, kakao, kelapa, karet, kapas, dan hasil perkebunan lainnya). Produk Domestik Bruto (PDB) Indonesia, produktivitas komoditas perkebunan Indonesia, harga ekspor komoditas perkebunan Indonesia, dan kurs rupiah terhadap dolar Amerika Serikat adalah variabel independen yang digunakan dalam penelitian ini.

Selanjutnya, untuk mengukur kinerja ekspor subsektor perkebunan selama masa pandemi Covid-19, penelitian ini menggunakan Tabel I-O Indonesia tahun 2016 klasifikasi 185 sektor yang merupakan versi terbaru dari Badan Pusat Statistik (BPS) tahun 2021. Tabel I-O tersebut kemudian diagregasi menjadi 21 sektor dengan rincian 12 komoditas perkebunan Indonesia. Tabel I-O yang digunakan adalah tabel transaksi domestik atas dasar harga dasar.

Data dalam penelitian ini didapatkan dari berbagai sumber dan instansi terkait seperti Badan Pusat Statistik (BPS), Direktorat Jendral Perkebunan (Ditjenbun), United Nations of Comodity Trade Database (UN-Comtrade), World Development Indicators (WDI) World Bank, World Integrated Trade Solution (WITS), serta berbagai sumber data pendukung seperti literatur dari berbagai publikasi ilmiah.

\section{Metode Analisis dan Pengolahan Data}

Metode analisis dalam penelitian ini telah disesuaikan dengan tujuan penelitian, yaitu metode analisis kuantitatif dan analisis InputOutput. Analisis kuantitatif dalam bentuk regresi berganda Ordinary Least Square (OLS) digunakan untuk mengetahui faktor-faktor yang memengaruhi ekspor subsektor perkebunan Indonesia serta analisis Input-Output yang digunakan untuk mengetahui dampak perubahan nilai ekspor subsektor perkebunan terhadap output, pendapatan, dan tenaga kerja selama masa pandemi Covid-19.

\section{Metode Ordinary Least Square}

Tujuan dari metode regresi berganda adalah untuk melihat pengaruh variabel bebas terhadap variabel terikat yang berkorelasi dengan bantuan software E-views 10 dan Microsoft Excel. Selanjutnya dilakukan uji kesesuain kriteria statistik yang meliputi:

- Uji F

Uji F dilakukan secara statistik untuk melihat apakah variabel independen memengaruhi variabel dependen dalam model secara keseluruhan. Apabila probabilitas dari F-statistik lebih kecil dari taraf nyata, disimpulkan bahwa variabel independen dalam model memengaruhi variabel dependen.

- Uji T

Uji T dilakukan secara statistik untuk melihat apakah variabel independen dalam model memengaruhi variabel dependen. Apabila probabilitas dari t-statistik lebih kecil dari taraf nyata, disimpulkan bahwa variabel independen di dalam model memengaruhi variabel dependen.

- Koefisien Determinasi

Koefisien determinasi atau $R$-square $\left(\mathrm{R}^{2}\right)$ merupakan penjelas bagi keragaman variabel dependen yang dijelaskan oleh variabel-variabel independen di dalam model. Oleh karena itu, koefisien determinasi dapat mengukur kebaikan model (goodness of fit). Semakin tinggi koefisien determinasi, semakin besar keragaman variabel dependen yang dapat dijelaskan oleh variabel independen di dalam model.

- Uji Asumsi Model

Analisis regresi mengandung tiga asumsi pengujian, yaitu heteroskedastisitas, autokolinearitas, dan multikolinearitas. Selain itu terdapat uji normalitas untuk mengetahui apakah model regresi memiliki error term distribusi normal. Keempat pengujian tersebut harus dilakukan untuk memdapatkan model BLUE (Blue Linear Unbiased Estimator) sehingga hasil estimasi model regresi ini bersifat efisien, konsisten, dan tidak bias. Estimasi model 
dalam penelitian ini menggunakan beberapa variabel sebagai betikut:

$$
\begin{aligned}
\operatorname{LnX}_{\mathrm{t}}= & \mathrm{C}+\beta_{1} \operatorname{Ln} \mathrm{PDB}_{\mathrm{t}}+\beta_{2} \mathrm{Ln} \mathrm{HE}_{\mathrm{t}}+\beta_{3} \mathrm{Ln} \\
& \mathrm{PRDV}_{\mathrm{t}}+\beta_{4} \mathrm{Ln} \mathrm{KURS}_{\mathrm{t}}+\varepsilon_{\mathrm{it}}
\end{aligned}
$$

Keterangan:

$\mathrm{X}_{\mathrm{t}} \quad=$ Nilai ekspor komoditas perkebunan pada tahun ke-t (USD)

$\mathrm{PDB}_{\mathrm{t}}=\mathrm{GDP}$ nominal Indonesia pada tahun ke-t (USD)

$\mathrm{HE}_{\mathrm{t}}=$ Harga ekspor komoditas sektor perkebunan pada tahun ke-t (USD/KG)

$\mathrm{PRDV}_{\mathrm{t}}=$ Produktivitas perkebunan Indonesia pada tahun ke-t (Ton/Ha)

$\mathrm{KURS}_{\mathrm{t}}=$ Kurs rupiah per dolar Amerika Serikat pada tahun ke-t $(\mathrm{Rp} / \$)$

$\mathrm{Ln}=$ Logaritma Natural

$\mathrm{C}=$ Intersep

$\beta_{\mathrm{n}} \quad=$ Slope

$\varepsilon_{\mathrm{it}} \quad=$ Error Term

2. Analisis Input-Output

Analisis Input-Output pada penelitian ini digunakan untuk mengetahui dampak perubahan nilai ekspor subsektor perkebunan Indonesia selama masa pandemi Covid-19. Analisis dampak berguna untuk melihat perubahan output, pendapatan, dan tenaga kerja pada sektor-sektor dalam perekenomian sebagai akibat dari adanya perubahan nilai ekspor pada subsektor perkebunan selama pandemi Covid-19. Selanjutnya analisis dampak dilakukan dengan memberikan shock berupa perubahan nilai ekspor pada subsektor perkebunan Indonesia. Nilai yang digunakan sebagai shock didasarkan pada besarnya perubahan nilai ekspor subsektor perkebunan sebelum (tahun 2019) dan pada masa pandemi Covid-19 (tahun 2020) yang besarannya dapat di lihat pada Tabel 2. Adapun rumus analisis dampak pada penelitian ini adalah (Firmansyah 2006):

a. Dampak terhadap pembentukan output

$$
\Delta \mathrm{X}=(\mathrm{I}-\mathrm{A})^{-1} \Delta \mathrm{Y}
$$

b. Dampak terhadap pendapatan rumah tangga

$$
\Delta \mathrm{H}^{*}=\mathrm{h}_{\mathrm{j}}(\mathrm{I}-\mathrm{A})^{-1} \Delta \mathrm{Y}
$$

c. Dampak terhadap penyerapan tenaga kerja

$$
\Delta \mathrm{E}^{*}=\mathrm{e}_{\mathrm{j}}(\mathrm{I}-\mathrm{A})^{-1} \Delta \mathrm{Y}
$$

\begin{tabular}{|c|c|c|c|c|c|}
\hline \multirow{2}{*}{$\begin{array}{l}\text { Kode } \\
\text { Sektor }\end{array}$} & \multirow{2}{*}{ Nama Sektor } & \multicolumn{2}{|c|}{ Nilai (US\$) } & \multirow{2}{*}{$\begin{array}{l}\text { Perubahan } \\
\text { (US\$) }\end{array}$} & \multirow{2}{*}{$\begin{array}{c}\text { Nilai Shock } \\
\text { (Juta Rupiah) }\end{array}$} \\
\hline & & 2019 & 2020 & & \\
\hline 2 & Tebu & 122378 & 37789 & -84589 & -1193 \\
\hline 3 & Tembakau & 60841400 & 63739100 & 2897700 & 40872 \\
\hline 4 & Tanaman serat & 7109600 & 7577100 & 467500 & 6594 \\
\hline 5 & $\begin{array}{l}\text { Hasil Perkebunan } \\
\text { Lainnya }\end{array}$ & 419312366 & 471101547 & 51789181 & 730486 \\
\hline 6 & Karet & 6474500 & 6558800 & 84300 & 1189 \\
\hline 7 & Kelapa & 222360405 & 397814901 & 175454496 & 2474785 \\
\hline 8 & Kelapa Sawit & 15574403600 & 18447953600 & 2873550000 & 40531422 \\
\hline 9 & Kopi & 872355400 & 809164200 & -63191200 & -891311 \\
\hline 10 & Teh & 11571400 & 14790700 & 3219300 & 45408 \\
\hline 11 & Kakao & 80621500 & 75807300 & -4814200 & -67904 \\
\hline 12 & Cengkeh & 107109000 & 173217300 & 66108300 & 932457 \\
\hline 13 & Jambu Mete & 176658559 & 146274725 & -30383834 & -428563 \\
\hline
\end{tabular}

Keterangan:

$$
\begin{aligned}
\Delta \mathrm{X}= & \text { dampak terhadap pembentukan output } \\
\Delta \mathrm{H}^{*}= & \text { dampak terhadap pendapatan rumah } \\
& \text { tangga } \\
\Delta \mathrm{E}^{*}= & \text { dampak terhadap penyerapan tenaga } \\
& \text { kerja } \\
\Delta \mathrm{Y}= & \text { perubahan final demand berupa } \\
& \text { ekspor di subsektor perkebunan } \\
(\mathrm{I}-\mathrm{A})^{-1}= & \text { matriks kebalikan Leontief } \\
\mathrm{h}_{\mathrm{j}}= & \text { koefisien pendapatan } \\
\mathrm{e}_{\mathrm{j}}= & \text { koefisien tenaga kerja }
\end{aligned}
$$

Tabel 2. Nilai shock ekspor subsektor perkebunan Indonesia tahun 2020

Sumber: BPS 2021 (diolah) 
Berdasarkan nilai shock yang ada, maka terdapat 12 komoditas subsektor perkebunan pada analisis dampak dalam penelitian ini yang meliputi tebu, tembakau, tanaman serat, hasil perkebunan lainnya, karet, kelapa, kelapa sawit, kopi, teh, kakao, cengkeh, dan jambu mete. Sehingga jika diklasifikasikan secara keseluruhan sektor-sektor dalam penelitian ini dapat di lihat pada Tabel 3.

Tabel 3. Klasifikasi sektor pada analisis dampak perubahan nilai ekspor subsektor perkebunan

\begin{tabular}{cl}
\hline Kode Sektor & \\
\hline 1 & Perikanan, Kehutanan, dan Perikanan \\
2 & Tebu \\
3 & Tembakau \\
4 & Tanaman serat \\
5 & Hasil Perkebunan Lainnya \\
6 & Karet \\
7 & Kelapa \\
8 & Kelapa Sawit \\
9 & Kopi \\
10 & Teh \\
11 & Kakao \\
12 & Cengkeh \\
13 & Jambu Mete \\
14 & Pertambangan dan Penggalian \\
15 & Industri Pengolahan \\
16 & Listrik, Gas, dan Air Bersih \\
17 & Bangunan \\
18 & Perdagangan, Hotel, dan Restoran \\
19 & Pengangkutan dan Komunikasi \\
20 & Keuangan, Real Estate, dan Jasa Perusahaan \\
21 & Jasa-Jasa \\
\hline
\end{tabular}

Sumber: BPS 2021 (diolah)

\section{HASIL DAN PEMBAHASAN}

1. Analisis Faktor-Faktor yang Memengaruhi Kinerja Ekspor Subsektor Perkebunan Indonesia

Hasil regresi linear berganda bertujuan untuk mengetahui faktor-faktor yang memengaruhi ekspor komoditas subsektor perkebunan Indonesia (kelapa sawit, kopi, teh, cengkeh, tembakau, kakao, kelapa, karet, kapas, dan hasil perkebunan lainnya) dengan menggunakan metode Ordinary Least Square $(O L S)$. Variabel dependen yang digunakan pada penelitian ini adalah PDB nominal Indonesia (PDB), harga ekspor komoditas subsektor perkebunan (HE), produktivitas subsektor perkebunan Indonesia (PRDV), dan kurs rupiah terhadap dolar AS (KURS). Data yang dianalisis menggunakan data time series selama 31 tahun (1990-2020).

Berdasarkan Tabel 4, uji-F dapat diperoleh dari nilai probabilitas F-Statistik dalam suatu model dengan nilai 0.000 . Nilai tersebut berada di bawah nilai taraf nyata $5 \%$, diartikan bahwa setidaknya terdapat satu variabel yang berpengaruh signifikan terhadap nilai ekspor subsektor perkebunan Indonesia. Sementara pada Tabel 4, uji-t di lihat berdasarkan masing-masing probabilitas variabel independen. Hasil estimasi uji-t menunjukkan bahwa variabel independen yaitu, PDB nominal Indonesia (PDB), harga ekspor komoditas subsektor perkebunan (HE), 
produktivitas subsektor perkebunan Indonesia (PRDV), dan kurs rupiah terhadap dolar AS (KURS) berdampak signifikan terhadap nilai ekspor subsektor perkebunan Indonesia.

Selanjutnya hasil estimasi regresi berganda Ordinary Least Square (OLS) menunjukkan bahwa model memiliki nilai $R$ Square sebesar 0.9876 yang berarti $98.76 \%$ keragaman variabel dependen dijelaskan oleh variabel-variabel independen pada model dan sisanya sebesar $1.24 \%$ dijelaskan oleh variabel di luar model. Model estimasi yang digunakan dalam ekspor subsektor perkebunan adalah sebagai berikut:

$$
\begin{aligned}
\operatorname{LnX}_{\mathrm{t}}= & 18.84147+0.040946 \mathrm{Ln} \mathrm{P} \mathrm{BB}_{\mathrm{t}}+ \\
& 1.159398 \mathrm{Ln} \mathrm{HE}+1.643673 \mathrm{Ln} \\
& \text { PRDV }_{\mathrm{t}}+0.325556 \mathrm{Ln} \mathrm{KURS}_{\mathrm{t}}+\varepsilon_{\mathrm{it}}
\end{aligned}
$$

Model tersebut telah di uji asumsi klasik untuk memperoleh model yang bersifat BLUE (Best Linear Unbiased Estimator). Uji multikolinearitas dilakukan dengan mem- bandingkan nilai probabilitas dan matriks korelasi antar variabel (Nasution et al. 2019). Nilai $R$-Square pada model sebesar 0.9876 dan keempat variabel yang digunakan signifikan, yang menjelaskan bahwa model terbebas dari multikolinearitas.

Uji autokolerasi dilakukan dengan melihat LM-test yang bertujuan untuk mengetahui korelasi antar error di dalam model (Maulana 2020). Uji LM-test menunjukkan Prob. Chisquare lebih besar dari taraf taraf nyata 5\%, sehingga disimpulkan bahwa tidak terdapat masalah autokolerasi pada model. Hasil uji normalitas dengan Jarque-bera test menunjukkan probabilitas sebesar 0.8921, dimana nilai tersebut lebih besar dari taraf nyata $5 \%$, hal tersebut menunjukkan error atau sisaan dalam model sudah terdistribusi normal. Uji heteroskedastisitas menggunakan BreuschPagan memperoleh nilai probabilitas sebesar 0.8653 , dimana lebih besar dari taraf nyata $5 \%$, sehingga model tidak memiliki masalah heteroskedastisitas.

Tabel 4. Hasil estimasi faktor yang memengaruhi nilai ekspor subsektor perkebunan Indonesia

\begin{tabular}{lccc}
\hline Variabel & Koefisien & t-Statistik & Probabilitas \\
\hline $\mathrm{C}$ & 18.841 & 22.390 & $0.000^{*}$ \\
$\mathrm{Ln} \mathrm{PDB}_{\mathrm{t}}$ & 0.040 & 3.540 & $0.001^{*}$ \\
$\mathrm{Ln} \mathrm{HE}_{\mathrm{t}}$ & 1.159 & 13.618 & $0.000^{*}$ \\
$\mathrm{Ln} \mathrm{KURS}_{\mathrm{t}}$ & 0.325 & 5.325 & $0.000^{*}$ \\
Ln PRDV $_{\mathrm{t}}$ & 1.643 & 9.076 & $0.000^{*}$ \\
\hline$R$-Square & 0.987 & & \\
Probabilitas F-Statistik & 0.000 & & \\
\hline
\end{tabular}

Keterangan : *) signifikan pada taraf nyata $5 \%$

Hasil estimasi OLS yang terdapat pada Tabel 4 menunjukkan bahwasanya PDB nominal Indonesia berpengaruh signifikan positif terhadap nilai ekspor subsektor perkebunan Indonesia karena memiliki nilai koefisien sebesar 0.0409 , artinya ketika PDB nominal Indonesia meningkat sebesar $1 \%$, maka ekspor subsektor perkebunan akan meningkat sebesar $0.0409 \%$. Penelitian ini 
memiliki kesamaan dengan penelitian Carolina dan Aminata (2019) yang menyatakan bahwa terjadinya peningkatan PDB nominal akan mendorong peningkatan output. Hal tersebut membuat kemampuan rata-rata penduduk suatu negara dalam melakukan produksi menjadi semakin besar sehingga kemampuan negara tersebut untuk mengekspor akan semakin meningkat.

Selanjutnya, berdasarkan Tabel 4 dapat diketahui bahwa harga ekspor memiliki hubungan signifikan positif terhadap nilai ekspor subsektor perkebunan Indonesia karena memiliki nilai koefisien sebesar 1.159, artinya jika harga ekspor subsektor perkebunan meningkat sebesar $1 \%$, maka ekspor subsektor perkebunan juga meningkat sebesar $1.1593 \%$. Hal ini sejalan dengan penelitian Hanoum dan Mulatsih (2016) dimana adanya peningkatan harga akan meningkatkan mutu dan kualitas terhadap komoditas tersebut, sehingga peningkatan yang terjadi pada harga akan menyebabkan peningkatkan pada nilai ekspor di pasar internasional.

Berdasarkan Tabel 4 dapat diketahui bahwa nilai tukar atau kurs rupiah terhadap dolar AS berpengaruh positif terhadap nilai ekspor subsektor perkebunan Indonesia karena memiliki nilai koefisien sebesar 0.3255 , artinya ketika terjadi penguatan kurs rupiah terhadap dolar AS sebesar $1 \%$ maka akan terjadi peningkatan ekspor subsektor perkebunan sebesar $0.3255 \%$. Uzomba et al (2012) menyatakan bahwa nilai tukar berperan positif terhadap ekspor. Hal ini semakin diperkuat oleh penelitian dari Hotsawadi (2020) yang menyatakan apabila terjadi peningkatan pada nominal nilai tukar rupiah (Rp.12.000/\$ menjadi Rp. 13.000/\$), maka mengindikasikan bahwa barang domestik negara pengekspor akan mengalami penurunan harga bagi negara pengimpor, sehingga nilai ekspor Indonesia mengalami peningkatan dengan asumsi cateris paribus.

Berdasarkan Tabel 4 dapat diketahui bahwa produktivitas subsektor perkebunan Indonesia memiliki hubungan positif dan signifikan terhadap nilai ekspor subsektor perkebunan Indonesia karena memiliki nilai koefisien sebesar 1.6436, artinya ketika terjadi peningkatan produktivitas subsektor perkebunan sebesar $1 \%$ maka akan mengalami peningkatan ekspor subsektor perkebunan sebesar $1.6436 \%$. Hal ini semakin diperkuat oleh penelitian Ghafoor et al. (2012) yang menjelaskan bahwa meningkatnya jumlah produksi akan sejalan dengan terjadinya kenaikan permintaan dari importir. Penelitian ini juga memiliki kesamaan dengan penelitian Gultom (2012) dimana terdapat pengaruh positif antara produktivitas lahan dengan daya saing ekspor pada komoditas kelapa sawit. Sehingga semakin meningkatnya produktivitas suatu komoditas akan menyebabkan ekspor dari komoditas tersebut semakin meningkat.

\section{Dampak Perubahan Nilai Ekspor Subsektor Perkebunan pada Masa Pandemi Covid-19}

Analisis kinerja ekspor subsektor perkebunan bertujuan untuk mengetahui sejauh mana dampak yang ditimbulkan sebagai akibat dari adanya perubahan nilai ekspor subsektor perkebunan pada masa pandemi Covid-19 tahun 2020 terhadap setiap sektor-sektor dalam perekonomian. Oleh karena itu, perubahan nilai ekspor selama masa pandemi Covid-19 tahun 2020 akan meningkatkan atau menurunkan output, pendapatan, dan tenaga kerja sektor-sektor dalam perekonomian Indonesia.

a. Dampak terhadap Output

Berdasarkan Tabel 5, dapat diketahui bahwa dampak dari adanya perubahan nilai ekspor subsektor perkebunan pada masa pandemi Covid-19 tahun 2020 akan memberikan tambahan output di semua sektor perekonomian sebesar Rp 58.33 triliun. Sektor yang menerima dampak peningkatan output paling besar adalah kelapa sawit dengan kenaikan output sebesar Rp 43.13 triliun atau $73.95 \%$ dari total peningkatan output sebagai akibat dari adanya perubahan nilai ekspor subsektor perkebunan pada masa pandemi Covid-19. Hal ini disebabkan 
karena kelapa sawit merupakan komoditas global yang mampu bersaing dan memiliki daya tahan terhadap goncangan yang baik serta mampu menyumbang pendapatan terhadap devisa yang lebih tinggi dibandingkan tahun 2019 sehingga kelapa sawit dapat diandalkan dalam menggerakkan perekonomian di masa pandemi Covid-19 (Azahari et al. 2020).

Sektor kedua yang mendapatkan kenaikan output paling besar yaitu industri pengolahan dengan kenaikan output sebesar Rp 4.07 triliun atau $6.99 \%$ dari total peningkatan output semua sektor perekonomian. Sektor pertanian, kehutanan, dan perikanan ialah sektor yang menerima pengaruh terbesar ketiga dengan kenaikan output sebesar $\mathrm{Rp} 2.66$ triliun atau $4.58 \%$ dari total peningkatan output semua sektor perekonomian. Hal ini terjadi karena secara umum ekspor komoditas pertanian pada periode Januari-Juli 2020 mengalami pertumbuhan rata-rata yang positif (Yofa et al. 2020).

Adanya perubahan nilai ekspor subsektor perkebunan pada masa pandemi Covid-19 tahun 2020 tidak hanya berdampak pada peningkatan output saja tetapi juga berdampak pada penurunan output di beberapa sektor perekonomian. Sektor yang mengalami penurunan output terbesar yaitu kopi dengan penurunan sebesar Rp 928.6 miliar atau $-1.59 \%$ dari total peningkatan output semua sektor perekonomian. Selanjutnya sektor kedua yang mengalami penurunan output terbesar yaitu jambu mete dengan penurunan sebesar Rp 431.4 miliar atau $-0.74 \%$ kemudian diikuti oleh kakao dengan penurunan sebesar Rp 56.3 miliar atau $0.10 \%$ dari total peningkatan output semua sektor.

b. Dampak terhadap Pendapatan

Berdasarkan Tabel 5, terlihat bahwa dampak perubahan nilai ekspor subsektor perkebunan pada masa pandemi Covid-19 tahun 2020 akan menghasilkan tambahan pendapatan sebesar Rp 19.99 triliun di semua sektor perekonomian. Sektor yang menerima dampak peningkatan pendapatan paling besar adalah kelapa sawit dengan kenaikan pendapatan sebesar $\mathrm{Rp} 16.42$ triliun atau $82.18 \%$ dari total peningkatan pendapatan sebagai akibat dari adanya perubahan nilai ekspor subsektor perkebunan pada masa pandemi Covid-19.

Sektor kedua yang mendapatkan kenaikan pendapatan paling besar adalah kelapa dengan peningkatan pendapatan sebesar Rp 851.1 miliar atau $4.26 \%$. Hal tersebut dikarenakan peluang ekspor kelapa semakin membesar dikarenakan adanya permintaan global dan perkembangan global value chain terhadap produk kelapa Indonesia (Naufal dan Suprehatin 2021). Sehingga selama masa pandemi, ekspor kelapa parut berhasil menembus pasar India, Vietnam, dan Malaysia (Kementan 2020). Selanjutnya diikuti oleh sektor pertanian, kehutanan, dan perikanan dengan peningkatan pendapatan sebesar Rp 828.2 miliar atau $4.14 \%$ dari total peningkatan pendapatan seluruh sektor perekonomian.

Adanya perubahan nilai ekspor subsektor perkebunan pada masa pandemi Covid-19 tahun 2020 tidak hanya berdampak pada peningkatan pendapatan saja, tetapi juga berdampak pada penurunan pendapatan di beberapa sektor perekonomian. Sektor yang mengalami penurunan pendapatan paling besar adalah kopi dengan penurunan sebesar Rp 386.3 miliar atau $-1.93 \%$ dari total peningkatan pendapatan semua sektor perekonomian. Selanjutnya sektor kedua yang mengalami penurunan pendapatan terbesar adalah jambu mete dengan penurunan sebesar Rp 155.9 miliar atau $-0.78 \%$ kemudian diikuti oleh kakao dengan penurunan sebesar Rp 17.2 miliar atau $-0.09 \%$ dari total peningkatan pendapatan semua sektor perekonomian.

c. Dampak terhadap Tenaga Kerja 
Berdasarkan Tabel 5 terlihat bahwa dampak perubahan nilai ekspor subsektor perkebunan selama masa pandemi Covid19 tahun 2020 akan memberikan tambahan penyerapan tenaga kerja sebesar 1.13 juta orang di semua sektor perekonomian. Sektor yang menerima dampak peningkatan penyerapan tenaga kerja paling besar adalah kelapa sawit dengan kenaikan tenaga kerja sebesar 999.68 ribu orang atau $87.86 \%$ dari total peningkatan penyerapan tenaga kerja sebagai akibat dari adanya perubahan nilai ekspor subsektor perkebunan pada masa pandemi Covid-19.

Sektor kedua yang mendapatkan kenaikan penyerapan tenaga kerja paling besar adalah kelapa dengan peningkatan penyerapan tenaga kerja sebesar 51.78 ribu orang atau $4.55 \%$ kemudian disusul oleh sektor pertanian, kehutanan, dan perikanan dengan peningkatan penyerapan tenaga kerja sebesar 50.39 ribu orang atau $4.43 \%$ dari total peningkatan penyerapan tenaga kerja seluruh sektor perekonomian.

Adanya perubahan nilai ekspor subsektor perkebunan pada masa pandemi Covid-19 tahun 2020 tidak hanya berdampak pada peningkatan penyerapan tenaga kerja saja tetapi juga berdampak pada penurunan penyerapan tenaga kerja di beberapa sektor perekonomian. Sektor yang mengalami penurunan penyerapan tenaga kerja paling besar adalah kopi dengan penurunan tenaga kerja sebesar 23.50 ribu orang atau $-2.07 \%$ dari total peningkatan penyerapan tenaga kerja seluruh sektor perekonomian. Selanjutnya sektor kedua yang mengalami penurunan penyerapan tenaga kerja terbesar adalah jambu mete dengan penurunan sebesar 9.48 ribu orang atau $-0.83 \%$ kemudian diikuti oleh kakao dengan penurunan penyerapan tenaga kerja sebesar 1.04 ribu orang atau $-0.09 \%$ dari total peningkatan penyerapan tenaga kerja semua sektor perekonomian.

Tabel 5. Dampak perubahan nilai ekspor subsektor perkebunan terhadap output, pendapatan, dan tenaga kerja

\begin{tabular}{|c|c|c|c|c|c|c|c|}
\hline \multirow{2}{*}{$\begin{array}{l}\text { Kode } \\
\text { Sektor }\end{array}$} & \multirow[t]{2}{*}{ Sektor } & \multicolumn{2}{|c|}{$\begin{array}{c}\text { Output } \\
\text { (Miliar Rupiah) }\end{array}$} & \multicolumn{2}{|c|}{$\begin{array}{c}\text { Pendapatan } \\
\text { (Miliar Rupiah) }\end{array}$} & \multicolumn{2}{|c|}{$\begin{array}{c}\text { Tenaga Kerja } \\
\text { (Orang) }\end{array}$} \\
\hline & & Nilai & Persen & Nilai & Persen & Nilai & Persen \\
\hline 1 & $\begin{array}{l}\text { Pertanian, Kehutanan, dan } \\
\text { Perikanan }\end{array}$ & 2669.3 & 4.58 & 828.2 & 4.14 & 50396 & 4.43 \\
\hline 2 & Tebu & 5.1 & 0.01 & 1.7 & 0.01 & 104 & 0.01 \\
\hline 3 & Tembakau & 50.1 & 0.09 & 12.4 & 0.06 & 755 & 0.07 \\
\hline 4 & Tanaman serat & 6.7 & 0.01 & 0.73 & 0.00 & 44 & 0.00 \\
\hline 5 & Hasil Perkebunan Lainnya & 740.3 & 1.27 & 273.5 & 1.37 & 16646 & 1.46 \\
\hline 6 & Karet & 28.6 & 0.05 & 12.7 & 0.06 & 777 & 0.07 \\
\hline 7 & Kelapa & 2520.9 & 4.32 & 851.1 & 4.26 & 51788 & 4.55 \\
\hline 8 & Kelapa Sawit & 43134.4 & 73.95 & 16429.1 & 82.18 & 999685 & 87.86 \\
\hline 9 & Kopi & -928.6 & -1.59 & -386.3 & -1.93 & -23506 & -2.07 \\
\hline 10 & Teh & 46.7 & 0.08 & 15.0 & 0.08 & 915 & 0.08 \\
\hline 11 & Kakao & -56.3 & -0.10 & -17.2 & -0.09 & -1048 & -0.09 \\
\hline 12 & Cengkeh & 946.7 & 1.62 & 320.9 & 1.61 & 19531 & 1.72 \\
\hline 13 & Jambu Mete & -431.4 & -0.74 & -155.9 & -0.78 & -9487 & -0.83 \\
\hline 14 & Pertambangan dan Penggalian & 315.7 & 0.54 & 52.5 & 0.26 & 396 & 0.03 \\
\hline 15 & Industri Pengolahan & 4079.3 & 6.99 & 565.9 & 2.83 & 9496 & 0.83 \\
\hline 16 & Listrik, Gas, dan Air Bersih & 118.5 & 0.20 & 9.5 & 0.05 & 132 & 0.01 \\
\hline
\end{tabular}




\begin{tabular}{rlrrrrrr}
\hline \multirow{2}{*}{$\begin{array}{c}\text { Kode } \\
\text { Sektor }\end{array}$} & \multicolumn{1}{c}{ Sektor } & \multicolumn{2}{c}{$\begin{array}{c}\text { Output } \\
\text { (Miliar Rupiah) }\end{array}$} & \multicolumn{2}{c}{$\begin{array}{c}\text { Pendapatan } \\
\text { (Miliar Rupiah) }\end{array}$} & \multicolumn{2}{c}{$\begin{array}{c}\text { Tenaga Kerja } \\
\text { (Orang) }\end{array}$} \\
\cline { 3 - 8 } & & \multicolumn{1}{c}{ Nilai } & Persen & \multicolumn{1}{c}{ Nilai } & Persen & \multicolumn{1}{c}{ Nilai } & Persen \\
\hline 17 & Bangunan & 672.9 & 1.15 & 126.3 & 0.63 & 1844 & 0.16 \\
18 & Perdagangan, Hotel, dan Restoran & 1489.0 & 2.55 & 42.5 & 2.13 & 12476 & 1.10 \\
19 & Pengangkutan dan Komunikasi & 805.5 & 1.38 & 126.9 & 0.64 & 2048 & 0.18 \\
20 & Keuangan, Real Estate, dan Jasa & 1941.6 & 3.33 & 428.5 & 2.14 & 3248 & 0.29 \\
& Perusahaan & 176.0 & 0.30 & 70.1 & 0.35 & 1518 & 0.13 \\
\hline & Jasa-Jasa & 58331.5 & 100.00 & 19991.6 & 100.00 & 1137766 & 100.00 \\
\hline
\end{tabular}

\section{SIMPULAN DAN SARAN}

\section{Kesimpulan}

Berdasarkan hasil analisis regresi berganda dengan metode OLS yang telah diuraikan, maka dapat disimpulkan bahwa PDB nominal Indonesia, harga ekspor komoditas subsektor perkebunan, produktivitas subsektor perkebunan, dan kurs rupiah terhadap dolar Amerika Serikat secara simultan berpengaruh signifikan positif terhadap ekspor subsektor perkebunan Indonesia selama periode tahun 1990-2020. Naik turunnya ekspor subsektor perkebunan dipengaruhi oleh naik turunnya variabel bebas PDB nominal Indonesia, harga ekspor komoditas subsektor perkebunan, produktivitas subsektor perkebunan, dan kurs rupiah terhadap dolar Amerika Serikat.

Selanjutnya, perubahan nilai ekspor subsektor perkebunan Indonesia di masa pandemi Covid-19 tahun 2020 memberikan tambahan bagi output, pendapatan, dan tenaga kerja bagi sektorsektor lain dalam perekonomian termasuk subsektor perkebunan itu sendiri. Secara sektoral, dampak tersebut terbagi menjadi dua, yaitu sektor yang mengalami peningkatan dan sektor yang mengalami penurunan. Sektor yang ekspornya meningkat dan berkontribusi penting terhadap peningkatan output, pendapatan, dan tenaga kerja adalah kelapa sawit, kelapa, serta pertanian, kehutanan dan perikanan. Sementara sektor yang mendapatkan dampak negatif paling besar adalah kopi, jambu mete, dan kakao.

\section{Saran}

Ekspor subsektor perkebunan Indonesia menjadi salah satu komponen penting dalam perekonomian Indonesia. Dalam rangka peningkatan kinerja ekspor subsektor perkebunan Indonesia, pemerintah hendaknya perlu memperhatikan faktor PDB nominal Indonesia, harga ekspor komoditas subsektor perkebunan, produktivitas subsektor perkebunan, dan kurs rupiah terhadap dolar AS.

Strategi kebijakan yang dapat disarankan untuk mencapai pertumbuhan ekonomi yang tinggi adalah pengembangan komoditas perkebunan potensi, yaitu kelapa sawit dan kelapa. Hak ini dikarenakan komoditas tersebut memperoleh pengaruh terbesar dari adanya kinerja ekspor subsektor perkebunan selama masa pandemi Covid-19 tahun 2020 baik dari segi output, pendapatan, dan tenaga kerja. Peningkatan kinerja subsektor perkebunan perlu dilakukan untuk mendorong peningkatan produktivitas sehingga dapat mempengaruhi peningkatan kinerja ekspor subsektor perkebunan.

Produktivitas kelapa sawit dan kelapa dapat ditingkatkan melalui inovasi teknologi, penyediaan bibit yang berkualitas, dan perluasan lahan perkebunan sehingga pada akhirnya dapat meningkatkan produksi. Selain itu, pemerintah perlu melakukan strategi pengembangan industri pengolahan kelapa sawit dan kelapa. Hal tersebut perlu dilakukan agar jumlah dan jenis diversifikasi produk turunan menjadi semakin bertambah karena Indonesia merupakan negara pengekspor olahan kelapa sawit dan kelapa merupakan tumbuhan tree of life yang semua bagiannya dapat dimanfaatkan. Sehingga daya saing dan peluang ekspor kelapa sawit dan kelapa Indonesia di pasar internasional dapat bertahan. 
Harapannya dorongan tidak hanya dilakukan terhadap dua komoditas tersebut, melainkan juga terhadap komoditas-komoditas subsektor perkebunan lainnya.

\section{DAFTAR PUSTAKA}

Azahari DH, Sinuraya JF, Rachmawati RR. 2020. Daya Tahan Sawit Indonesia pada Era Pandemi COVID-19. (3):61-81.

Berata IKEW, Setiawina ND. 2017. Pengaruh Luas Lahan, Jumlah Produksi, Kurs Dolar Amerika Serikat dan Inflasi terhadap Ekspor Kakao Indonesia Kurun Waktu 1994-2013. Jurnal Ekonomi Pembangunan Universitas Udayana. 6(1): 36-63.

[BPS] Badan Pusat Statistik. 2020. (Seri 2010) Laju Pertumbuhan Produk Domestik Bruto (Persen). [Internet]. [diunduh 2021 Okt 15]. Tersedia pada: https://www.bps.go.id/indicator/11/104/2/seri-2010-laju-pertumbuhan-pdb-seri2010.html.

[BPS] Badan Pusat Statistik. 2020. Penduduk 15 tahun ke atas yang bekerja menurut lapangan kerja utama 2011-2020. [Internet]. [diunduh 2021 Okt 15]. Tersedia pada: https://www.bps.go.id/statictable/2009/04/16 1970/penduduk-15-tahun-ke-atas-yangbekerja-menurut-lapangan-pekerjaanutama-1986---2018.html.

[BPS] Badan Pusat Statistik. 2021. Pengertian Pendapatan Nasional. [Internet]. [diunduh 2021 Okt 31]. Tersedia pada: https://www.bps.go.id/.

[BPS] Badan Pusat Statistik. 2020. Produk Domestik Bruto Indonesia Seri 2010. [Internet]. [diunduh 2021 Okt 15]. Tersedia pada:

https://www.bps.go.id/indicator/11/65/2/seri-2010-pdb-seri-2010.html.

[BPS] Badan Pusat Statistik. 2021. Produktivitas Tanaman Pangan. [Internet]. [diunduh 2021 Okt 29]. Tersedia pada: https://sirusa.bps.go.id/sirusa/index.php/indi kator/551.

[BPS] Badan Pusat Statistik. 2021. Tabel inputoutput Indonesia 2016. Jakarta (ID): Badan
Pusat Statistik.

Carolina LK, Aminata J. 2019. Analisis Daya Saing dan Faktor yang Memengaruhi Ekspor Batu Bara. Diponegoro Journal of Economics. 1(1): 9-21.

Dewi NAS. 2018. Pengaruh GDP, Inflasi, dan Exchange Rate terhadap Ekspor dan Impor di Indonesia Tahun 1980-2016 [skripsi]. Surakarta (ID): Universitas Muhammadiyah Surakarta.

[Ditjenbun] Direktorat Jendral Perkebunan. 2020. Peluang ekspor perkebunan masih bertahan. [Internet]. [diunduh 2021 Nov 25]. Tersedia pada:

https://ditjenbun.pertanian.go.id/2020/.

[Ditjenbun] Direktorat Jenderal Perkebunan.

2021. Statistik Perkebunan Unggulan Nasional tahun 2019-2021. [Internet]. [diunduh 2021 Okt 10]. Tersedia pada: https://drive.google.com/file/d/IZpXeZogAQ YfClNBOgVLhYi8X_vujJdHx/view

Firmansyah. 2006. Operosi Matrix dan Analisis Input-Output (I-O) untuk Ekonomi. Semarang (ID): Badan Penerbit Universitas Diponegoro.

Ghafoor A, Aslam M, Rasool S. 2012. Determinants of Leather Goods Exports: A Case of Pakistan. Journal of Business and Economics. 4(2): 256-269.

Goenadhi L, Nobaiti. 2017. Pengantar Ekonomi Mikro. Banjarmasin (ID): Scripta Cendekia.

Gultom RM. 2012. Pengaruh Produktivitas Lahan dan Nilai Tambah terhadap Daya Saing Komoditas Minyak Kelapa Sawit. Jurnal Ekonomi Pembangunan. 10(2): 82-103.

Hanoum FN, Mulatsih S. 2016. Analisis Kinerja Ekspor Elektronika Indonesia ke Amerika Latin. Jurnal Ekonomi dan Kebijakan Pembangunan. 5(1): 90-102.

Hasan M, Azis M. 2018. Pembangunan Ekonomi \& Pemberdayaan Masyarakat: Strategi Pembangunan Manusia dalam Perspektif Ekonomi Lokal.

Helena J. Purba, Eddy S. Yusuf, E. (2020). Pertumbuhan Ekonomi Terhadap Dan Sektor Pertanian. Dampak Pandemi Covid19: Perspektif Adaptasi Dan Resiliensi Sosial Ekonomi Pertanian, 23-46.

Hotsawadi. 2020. Diversifikasi Ekspor Non 
Migas Indonesia ke Pasar Non Tradisional [skripsi]. Bogor (ID): Institut Pertanian Bogor.

[Kementan] Kementrian Pertanian. 2020. Statistik Ketenagakerjaan Sektor Pertanian (Agustus 2020). Pusat Data Dan Sistem Informasi Pertanian, 68(1), 122.

[Kementan] Kementrian Pertanian. 2020. Outlook Kelapa 2020. [Internet]. [diunduh 2021 Okt 15]. Tersedia pada: http://epublikasi.setjen.pertanian.go.id/arsip -outlook/75-outlook-perkebunan/726outlook-kelapa-2020.

Kristanto J. 2011. Manajemen Pemasaran Internasional: Sebuah Pendekatan Strategi. Jakarta (ID): Erlangga.

Lomban SD. 2021. Covid-19 dan Kinerja Ekspor Sektor Pertanian di Indonesia. [Skripsi]. Bogor (ID): Institut Pertanian Bogor.

Malba E, Taher IM. 2016. Analisis Input-Output atas Dampak Sektor Pariwisata terhadap Perekonomian Maluku. Bina Ekon. 20(2):213-229. doi:10.26593/be.v20i2.2310.213-229.

Mankiw GN. 2006. Makroekonomi Edisi Enam. Jakarta (ID): Erlangga.

Maulana AD. 2020. Analisis Pengaruh FaktorFaktor Ekonomi terhadap Perkembangan FDI di Indonesia (Periode Tahun 19892018) [skripsi]. Bogor (ID): Institut Pertanian Bogor.

Nainggolan, Z., Purba, M. L., \& Sihotang, J. (2021). Analisis Pengaruh Jumlah Produksi, Nilai Tukar, dan Harga Internasional Terhadap Ekspor Tembakau Indonesia tahun 1990-2019. Journal of Economics and Business, 2(2), 18-28.

Nasution WN, Multasih S. 2019. Analisis kinerja ekspor alas kaki Indonesia ke kawasan Asean. Jurnal Ekonomi dan Kebijakan Pembangunan. 8(2): 182-204.

Naufal H Al, Suprehatin. 2021. Daya Saing Produk Kelapa Indonesia dan Eksportir Kelapa Utama Lainnya Di Pasar Global. 21(1):24-31.

Nussy VJM. 2021. Covid-19 Dan Kinerja Ekspor Sektor Agroindustri Indonesia. [Skripsi]. Bogor (ID): Institut Pertanian Bogor.

Oktaviani R, Novianti T. 2009. Teori
Perdagangan Internasional dan Aplikasinya di Indonesia. Departmen Ilmu Ekonomi. Bogor (ID): Institut Pertanian Bogor.

Priyatno D. 2012. Cara Kilat Belajar Analisis Data dengan SPSS 20. Yogyakarta (ID): Andi.

[Pusdatin] Pusat Data dan Informasi Kementrian Pertanian. 2020. Realisasi KUR picu PDB pertanian tumbuh positif. [Internet]. [diunduh 25 Des 2021]. Tersedia pada: https://pusdatin.setjen.pertanian.go.id/

Raharja, I. K. S. Y., \& Setyari, N. P. W. (2020). Analisis Determinan Ekspor Komputer Indonesia. Jurnal Ekonomi Pembangunan Universitas Udayana, 9(2), 444-472.

Sahara. 2017. Analisis Input-Output Perencanaan Sektor Unggulan. Bogor (ID): IPB Press.

Salvatore D. 1997. Ekonomi Internasional. Haris M, penerjemah. Jakarta (ID): Erlangga. Terjemahan dari: International economic.

Sambuaga J. 2020. Menjaga Pasar Ekspor Sawit di Kala Pandemi. Jakarta (ID): Kementrian Perdagangan.

Soekartawi. 2005. Agribisnis: Teori dan Aplikasinya. Cetakan Kedelapan. Edisi Pertama. Jakarta (ID): Raja Grafindo Persada.

Siringo H, Daulay M. 2014. Analisis Keterkaitan Produktivitas Pertanian Dan Impor Beras di Indonesia. J Ekon dan Keuang. 2(8):14808.

Sudaryanto T, Suharyono S. 2020. Peningkatan Daya Tahan Pertani dan Usaha Tani Terhadap Pandemi Covid-19. Dampak Pandemi Covid-19 Perspekt Adapt dan Resiliensi Sos Ekon Pertan.(3):725-741.

Uzomba PC, Imoisi AI, Somairi. 2012. The Impact of Macroeconomic Variables on Non-Oil Exports Performance in Nigeria 1989-2010. A Journal of Contemporary Reasearch. 9(1): 1-17.

[WDI] World Development Indicators. 2021. GDP (Current US\$) [internet]. [diunduh 2021 Okt 04]. Tersedia pada: https://data.worldbank.org/indicator/NY.GD P.MKTP.CD?locations $=I D$.

[WDI] World Development Indicators. 2021. Official Exchange Rate (LCU per US\$, 
Period Average) [internet]. [diunduh 2021

Okt 23]. Tersedia pada:

https://data.worldbank.org/indicator/PA.NU S.FCRF?locations $=I D$.

Wibowo T. 2013. Dampak Penurunan Ekspor Terhadap Penyerapan Tenaga Kerja. Bul Ilm Litbang Perdagang. 7(2):171-192. http://jurnal.kemendag.go.id/index.php/bilp/ article/view/112.

[WITS] World Integrated Trade Solution. 2021.
Total Ekspor Sub Sektor Perkebunan Indonesia [internet]. [diunduh 2021 Oktober 04]. Tersedia pada: http://wits.worldbank.org/.

Yofa RD, Erwidodo, Suryani E. 2020. Dampak Pandemi COVID-19 Terhadap Ekspor dan Impor. Dampak Pandemi Covid-19 Perspekt Adapt dan Resilensi Ekon Pertan. d(3):159181. 